\title{
Menelaah Persoalan Kemiskinan Melalui Narasi Persembahan Janda Miskin (Markus 12:41-44)
}

\author{
Yane Octavia Rismawati Wainarisi \\ Sekolah Tinggi Teologi Pelita Dunia Tangerang \\ yaneoctavia@gmail.com
}

\begin{abstract}
This article discusses the study of the problem of poverty based on the narrative of the offering of the poor widow in Mark 12: 41-44. By using qualitative methods or more precisely literature review, the authors conclude that there needs to be an encounter with them beforehand so that through encounters with poor people, both writers and we can also gain a deeper understanding of God's heart, not only for ourselves, for the poor and the weak, but also for everyone around the world. However, because poor people are the most vulnerable people to be treated unfairly, it is necessary to formulate solidarity with the poor in order to realize the Kingdom of God in the world.
\end{abstract}

Keywords: Poverty, Poor Widow's Offering, Mark

Abstrak: Artikel ini membahas tentang telaah persoalan kemiskinan yang didasarkan pada narasi persembahan janda miskin dalam Markus 12: 41-44. Dengan menggunakan metode kualitatif atau lebih tepatnya kajian pustaka, maka penulis menyimpulkan bahwa perlu ada perjumpaan terlebih dahulu dengan mereka agar melalui perjumpaan dengan orang-orang miskin, baik penulis dan kita juga dapat memperoleh pemahaman yang lebih tentang hati Allah, tidak hanya bagi kita sendiri, bagi orang-orang miskin dan lemah, namun juga bagi setiap orang diseluruh dunia. Namun karena orang-orang miskin merupakan orang-orang yang paling rentan untuk mendapat perlakukan tidak adil, maka perlu suatu formulasi solidaritas terhadap kaum miskin demi mewujudkan Kerajaan Allah di dunia.

Kata Kunci: Kemiskinan, Persembahan Janda Miskin, Markus

\section{Pendahuluan}

Miskin ataupun kemiskinan merupakan suatu masalah yang terjadi sejak zaman dahulu, namun masih belum dapat diselesaikan sampai saat ini. Kemiskinan menjadi pergumulan tidak hanya bagi perorangan namun juga bagi suatu komunitas masyarakat bahkan negara dan dunia. Kemiskinan menjadi suatu momok menakutkan bukan hanya dari kalangan awam namun juga kalangan rohaniawan. Para politikus juga "ngeri" dengan istilah ini apalagi jika istilah ini dikaitkan dengan status atau menjadi identitas yang melekat pada subyeknya. Adalah sesuatu yang menyedihkan jika sebuah Negara disebut sebagai "Negara Miskin". Namun demikian, bagaimanapun juga, kemiskinan itu sendiri adalah fakta kehidupan.

\section{Metode Penelitian}

Pada penelitian ini, penulis atau peneliti menggunakan pendekatan atau metode kualitatif untuk memperoleh data yang valid guna membangun sebuah teori yang berkaitan dengan tema atau pokok penelitian. Metode kualitatif yang dimaksud 
adalah mengkaji dan mengelaborasi setiap sumber, informasi dan data-data yang diperoleh dari pustaka.

\section{Hasil dan Pembahasan Definisi Miskin}

Istilah "miskin" memiliki makna yang ambigu. Masih ada beberapa orang dengan sejumlah penghasilan, properti, simpanan yang cukup besar di akun Banknya akan menyebut dirinya miskin dan ikut serta dalam program bantuan pemerintah untuk warga miskin. Ada juga beberapa orang yang nyata-nyata tidak memiliki banyak harta, tanpa properti, tidak memiliki banyak simpanan, tidak mau menerima bantuan dari orang lain ataupun pemerintah karena merasa dirinya cukup. Beberapa Negara di dunia juga disebut sebagai negara "miskin" karena alasan pendapatan nasional bruto mereka yang rendah berbanding terbalik dengan nilai konsumsinya.

Kata "miskin" dalam Kamus Besar bahasa Indonesia berarti tidak berharta, serba berkekurangan atau berpenghasilan sangat rendah. ${ }^{1}$ Merriam Webster Dictionary memberi definisi kata "miskin' sebagai suatu keadaan di mana seseorang kekurangan harta benda, tidak berkecukupan, inferior dalam hal kualitas atau nilai, atau suatu keadaan di mana tidak memiliki pasokan yang normal atau memadai untuk sesuatu yang dispesifikasikan. ${ }^{2}$ Oxford Dictionary mendefinisikan kata "miskin" sebagai kurangnya uang yang cukup untuk hidup pada standar yang dianggap nyaman atau normal dalam suatu masyarakat. ${ }^{3}$ Dalam kaitannya dengan keuangan, Cambridge Dictionary mendefinisikan kata "miskin" sebagai suatu keadaan di mana seseorang hanya memiliki sedikit uang atau harta. Dalam kata sifatnya, kata "miskin" ini berarti bahwa sesuatu itu memiliki kualitas atau standar yang rendah atau tidak baik. Pengertian lain dari kata "miskin" ini sendiri adalah suatu keadaan di mana seseorang atau sesuatu layak mendapat perhatian khusus. ${ }^{4}$ Badan Pusat Statistik Indonesia mengeluarkan pengertian penduduk miskin sebagai orang-orang yang memiliki rata-rata pengeluaran perkapita perbulan dibawah garis kemiskinan. ${ }^{5}$ Jika pada Sepetember 2017 total pengeluaran perkapita/bulan masyarakat perkotaan adalah Rp. 400.995,00., maka penduduk yang mengeluarkan uang untuk membiayai kebutuhan di bawah nominal tersebut dinyatakan sebagai golongan penduduk yang miskin.

Istilah kemiskinan memiliki dua pendekatan yaitu pendekatan individual dan struktural. Kemiskinan secara individual terjadi ketika seseorang bersikap malas, tidak kreatif, tidak kompetitif, tidak tekun dan tidak disiplin. Kemiskinan seperti ini timbul dari dalam diri seseorang itu sendiri dan bisa diatasi dengan pendidikan, pembinaan, pelatihan, dll. Kemiskinan tipe kedua adalah kemiskinan struktural yaitu kemiskinan yang terjadi karena faktor dari luar diri seseorang seperti penindasan, penghisapan, dll. Untuk tipe ini, struktur sosial merupakan penyebab seseorang jatuh dalam kemiskinan. Orang miskin dalam hal ini merupakan hasil dari produk sosial yang tidak adil. Kemiskinan secara stuktural biasanya lahir dari kebergantungan suatu masyarakat kepada masyarakat lain yang lebih berkuasa di atasnya baik secara

\footnotetext{
${ }^{1}$ https://www.kbbi.web.id/miskin diunduh 11 Mei 2018.

${ }^{2} \mathrm{https}: / /$ www.merriam-webster.com/dictionary/poor diunduh 11 Mei 2018.

${ }^{3} \mathrm{https} / / / \mathrm{en}$. oxforddictionaries.com/definition/poor diunduh $11 \mathrm{Mei} 2018$.

${ }^{4}$ https://dictionary.cambridge.org/dictionary/english/poor diunduh 11 Mei 2018.

${ }^{5}$ Profil Kemiskinan di Indonesia September 2017 No. 05/01/Th. XXI, 2 Januari 2018, 3.
} 
ekonomi, sosial maupun politik. Kemiskinan model ini menghasilkan dominasi kekuasaan, penindasan, kebergantungan, dll. ${ }^{6}$

Gustavo Gutierrez, seorang tokoh Teologi Pembebasan Amerika Latin, menilai kemiskinan sebagai suatu istilah yang samar-samar bahkan terkesan ambigu. Bagi Gutierres, kemiskinan memiliki setidaknya dua arti yang pertama berarti miskin secara material yang kedua berarti miskin secara spiritual. Secara material, seperti bahasan dalam tema ini, seseorang dikatakan miskin hanya jika ia tidak memiliki cukup banyak harta untuk dapat hidup dalam suatu kehidupan yang baik. Umumnya, kemiskinan dalam bentuk seperti ini ditolak oleh banyak orang. Bagaimana pun juga hal ini disebabkan oleh nilai material yang bersifat positif sehingga mendatangkan keinginan semua orang, termasuk orang Kristen dan gereja sendiri, untuk memiliki harta atau kekayaan. Di lain pihak, beberapa orang mungkin melihat kekayaan sebagai suatu cara untuk memberkati orang-orang miskin, namun hal ini jarang terjadi. Yang jelas adalah, kekayaan membuat seseorang memiliki nilai status sosial dan politik yang tinggi di mata masyarakat luas. ${ }^{7}$

Dalam Alkitab, kemiskinan juga memiliki pengertian yang ambigu. Meski demikian, kemiskinan sendiri sudah menjadi tema sentral baik dalam PL maupun PB yang digambarkan secara singkat dan mendalam dalam Alkitab. ${ }^{8}$ Kemiskinan menggambarkan situasi sosial dan ekspresi pengalaman spiritual yang terkomunikasi melalui dan dalam kesulitan-kesulitan, mendeskripsikan juga tentang sikap personal seseorang di hadapan sesamanya dan Tuhan dan relasi yang terjalin dengan orangorang disekitarnya. Sejak awal, Alkitab melihat orang yang miskin sebagai orang yang hampir mati dalam kelaparan, buta huruf dieksploitasi oleh orang lain namun tidak mengetahui bahwa mereka sedang dieksploitasi, dan tidak memahami bahwa ia adalah seorang manusia. Dalam pengertian ini, kemiskinan memiliki pengertian material, budaya, kolektif dan militant. ${ }^{9}$ Namun demikian, jika ditilik lebih dalam, menurut Gutierrez, ada dua pengertian dari kemiskinan yaitu sebagai suatu kondisi yang memalukan dan spiritualitas yang masih muda. ${ }^{10}$

Masih dalam konteks Alkitab, kemiskinan merupakan suatu kondisi yang bertentangan dengan martabat kemanusiaan dan berlawanan dengan kehendak Allah. ${ }^{11}$ Dalam PL istilah yang digunakan untuk kata miskin adalah rash yang memiliki makna netral. Orang miskin atau dalam bahasa aslinya ebyon yaitu seseorang yang memiliki harapan-harapan, pengemis, seseorang yang merasakan kekurangan sesuatu, dan yang mengharapkan sesuatu terhadap orang lain. Orang miskin juga disebut dengan dal atau seseorang yang lemah. Orang miskin juga biasa disebut dengan ani yang berarti seseorang yang membungkukkan diri terhadap orang lain, seseorang yang bekerja di bawah tekanan, seseorang yang sedang tidak berada dalam seluruh kekuatan dan tenaga miliknya, atau seseorang yang terhina. Seorang yang miskin juga merupakan seorang yang anaw atau seseorang yang "rendah hati di hadapan Allah." Dalam PB, istilah yang digunakan untuk

\footnotetext{
${ }^{6}$ Marthin Chen, Teologi Gustavo Gutierrez: Refleksi dari Praksis Kaum Miskin (Yogyakarta: Kanisius, 2002), 52 .

${ }^{7}$ Gustavo Gutierez, A Theology of Liberation: History, Politics, and Salvation (New York: Orbis Book, 1983), 289

${ }^{8}$ Gutierez, A Theology of Liberation, 291.

${ }^{9}$ Gutierez, A Theology of Liberation, 291.

${ }^{10}$ Gutierez, A Theology of Liberation, 291. Spiritualitas yang masih muda ini mengindikasikan suatu keadaa spiritual di mana seseorang merasa bergantung penuh kepada Allah, membuka diri sepenuhnya di hadapan Allah dan untuk dipakai oleh Allah, dan menunjukkan juga suatu kerendah-hatian di hadapan Allah.

${ }^{11}$ Gutierez, A Theology of Liberation, 291.
} 
menggambarkan tentang kemiskinan berasal dari kata ptokos yang digunakan untuk menyebut seorang yang miskin. Ptokos berarti seorang yang tidak memiliki apa yang dibutuhkan, seorang yang malang yang didorong untuk meminta-minta dan selalu membutuhkan pertolongan dari orang lain. Dalam Alkitab, iklim atau suasana kemiskinan digambarkan sebagai sesuatu yang penuh kemarahan. Kemarahan ini sama dengan yang terjadi terhadap penyebab dan akibat dari kemiskinan itu sendiri yaitu ketidakadilan dan tekanan-tekanan. ${ }^{12}$

\section{PARADIGMA SOSIAL TENTANG KEMISKINAN DITINJU DARI NARASI JANDA MISKIN DALAM MARKUS 12:41-44}

Kitab Markus merupakan salah satu Injil Sinoptik yang terletak di antara Matius dan Lukas. Menurut Barclay, di antara kitab-kitab lainnya, kitab ini dianggap yang terpenting dan merupakan kitab Injil yang paling penting di dunia. Hal ini didasarkan pada alasan bahwa kitab ini merupakan Injil tertua dan/atau merupakan cerita pertama tentang kehidupan Yesus. Meskipun Markus sendiri bukan pendengar pertama kata-kata Tuhan, tapi ia adalah pendengar/perekam khotbah Petrus sehingga dengan demikian, ia adalah pemberi informasi yang paling dekat tentang kehidupan Yesus. Hal ini terlihat dari kedekatan hubungan Petrus dan Markus (I Pet 5:13). ${ }^{13}$ Baik Matius maupun Lukas menggunakan tulisan Markus sebagai referensi buku mereka; ${ }^{14}$ meskipun pada faktanya, pada awal abad kedua, kedua Injil sinoptik lain yang lebih sering digunakan oleh orang-orang Kristen mula-mula. ${ }^{15}$ Karena itu, jika seseorang ingin mengadakan pendekatan terhadap biografi Yesus, Barclay menyarankan bahwa sebaiknya, kitab Markus menjadi referensinya. ${ }^{16}$

Tulisan yang ada dalam kitab Markus adalah fakta, dikemas paling sederhana dan dramatis. Markus menggambarkan Yesus sebagai sosok ilahi sekaligus manusiawi. Bagi Markus, Yesus adalah Allah di tengah-tengah manusia yang selalu membuat orang tercengang-cengang dengan kata-kata dan perbuatan-Nya. ${ }^{17}$ Pada saat yang sama, Yesus juga adalah sosok manusia biasa $(6: 3 ; 13: 55 ; 1: 12 ; 11: 12 ; 6: 3)$, sementara penulis lain memperlunak kata-kata mereka, Markus menggambarkan Yesus apa adanya. Bahkan, menurut Barclay, hanya Markus yang menggambarkan Yesus memandang anak muda yang kaya dengan kasih (10:21). Gambaran yang diberikan Markus tentang Yesus dalam cara yang seperti ini membuat Yesus terasa begitu dekat dengan manusia. Markus menulis dengan gaya bahasa yang hidup dan apa adanya. ${ }^{18}$ Kuatnya sisi kemanusiaan Yesus seperti yang digambarkan oleh Injil Markus membuat Injil ini mendapat perhatian para Teolog Yesus Sejarah pada abad ke-20-an. ${ }^{19}$ Berbanding terbalik dengan Barclay, menurut Jerome, kitab ini merupakan Injil yang membingungkan dan menggambarkan Yesus sebagai sosok misterius. Markus pada satu kesempatan menjelaskan bahwa para murid tidak paham tentang kata-kata Yesus namun ia sendiri tidak menjelaskan di mana letak ketidakpahaman tersebut. Injil ini dituliskan oleh Markus seumpama teka-teki dan pembaca diminta menjawab sendiri setiap kejadian yang digambarkan oleh

\footnotetext{
${ }^{12}$ Gutierez, A Theology of Liberation, 291-92.

${ }^{13}$ William Barclay, Pemahaman Alkitab Setiap Hari: Injil Markus (Jakarta: BPK Gunung Mulia, 2003),

${ }^{14}$ Barclay, Pemahaman Alkitab Setiap Hari, 3.

${ }^{15}$ Barclay, Pemahaman Alkitab Setiap Hari, 5.

${ }^{16}$ Barclay, Pemahaman Alkitab Setiap Hari, 9.

${ }^{17}$ Barclay, Pemahaman Alkitab Setiap Hari, 9.

${ }^{18}$ Barclay, Pemahaman Alkitab Setiap Hari, 11-12.

${ }^{19}$ J. Delorme, Injil Markus (Yogyakarta: Kanisius, 1978), 5.
} 7. 
Markus. $^{20}$ Sumbernya sendiri merupakan tradisi oral atau bahan-bahan yang ditemukan dalam jemaat Kristen, yang disusun secara pribadi dan khas oleh Markus. ${ }^{21}$

Penulis tertarik memilih teks Markus 12:41-44 untuk mengungkap realitas kemiskinan dalam tradisi masyarakat Yahudi yang lebih dekat dengan realitas aslinya, pada masa pelayanan Yesus, yang tergambar melalui ruangan persembahan di Bait Suci meskipun ada teks paralelnya pada Lukas 21:1-4. Penulis melihat bahwa ruangan persembahan merupakan salah satu tempat paling konkret untuk menggambarkan tentang kemiskinan, keadilan atau perlakuan tidak adil terhadap kaum miskin pada masyarakat Yahudi sekaligus menggambarkan korupsi para rohaniawan dan pemanfaatan persembahan demi kepentingan pemberi persembahan dan pengelola persembahan yang terjadi dalam Bait Suci pada masa itu. Menurut penulis, tradisi persembahan dan ruangan persembahan merupakan stigma umum yang terjadi pada masyarakat Yahudi masa itu.

\section{Teks Markus 12:41-44}

Pada suatu kali Yesus duduk menghadapi peti persembahan dan memperhatikan bagaimana orang banyak memasukkan uang ke dalam peti itu. Banyak orang kaya memberi jumlah yang besar. Lalu datanglah seorang janda yang miskin dan ia memasukkan dua peser, yaitu satu duit. Maka dipanggil-Nya murid-murid-Nya dan berkata kepada mereka: "Aku berkata kepadamu, sesungguhnya janda miskin ini memberi lebih banyak dari pada semua orang yang memasukkan uang ke dalam peti persembahan. Sebab mereka semua memberi dari kelimpahannya, tetapi janda ini memberi dari kekurangannya, semua yang ada padanya, yaitu seluruh nafkahnya."

Untuk lebih memahami tentang persoalan sosial di antara orang-orang Yahudi masa itu yang tersirat dalam ruangan persembahan melalui pemberian persembahan janda miskin ini, penulis telah membagi beberapa pokok pikiran sebagai berikut:

\section{Pendenahan Ruang Persembahan}

Dalam bagian ini, penulis mencoba menggambarkan teks ini dari sisi beberapa sisi, seperti:

a. Lokasi Kejadian

Teks ini mengambil lokasi di Bait Suci Yerusalem tepatnya di tempat perbendaharaan atau tempat persembahan. Setelah Yesus mengajar orang-orang kafir atau orang-orang di luar Yahudi dan meninggalkan ruangan mereka, Yesus dan rombongan mendekati ruang para perempuan di antara perbatasan antara ruangan kaum perempuan dan laki-laki. Ruangan bagi para perempuan ini dapat menampung sekitar 5000 orang. Di dekat tempat pertemuan para perempuan tersebut terdapat ruang persembahan. Ini juga yang menjadi penyebab janda miskin dalam teks ini dapat menghantarkan persembahan ke sana. ${ }^{22}$ Di dalam ruang persembahan ini terdapat tiga belas kotak besar persembahan besar yang berbentuk terompet dengan ujung yang terbuka agar orang dapat memasukkan persembahan ke dalamnya. Tujuannya adalah jika seseorang memberikan persembahan, maka jumlah dari persembahan itu akan segera ketahuan dan orang yang memberikan persembahan

\footnotetext{
${ }^{20}$ Delorme, Injil Markus, 7.

${ }^{21}$ Delorme, Injil Markus, 7.

22 James R. Edwards, The Gospel According to Mark. Grand Rapids: William B. Eerdmans, 2002), 380.
} 
juga dapat memberi tahu kepentingannya dalam memberikan persembahan tersebut. Sembilan dari kotak yang ada adalah kotak untuk pembayaran pajak dan persembahan kurban, empat tempat persembahan lainnya diperuntukkan untuk jual beli kayu, dupa, dekorasi Bait Suci, dan korban bakaran. ${ }^{23}$

b. Jumlah Persembahan bukan Rahasia

Jika pada masa kini, orang-orang terutama dalam budaya Timur sering menyembunyikan jumlah persembahan yang mereka berikan, maka pada masyarakat Yahudi masa itu, jumlah persembahan terutama kurban seperti dalam PL diatur berdasarkan ketetapan Hukum Taurat. Teks ini menunjukkan bahwa Yesus berdiri di dekat ruang persembahan tersebut, sebuah tempat yang tidak jauh dari kotak persembahan sehingga Yesus dan para murid dapat dengan mudah mengetahui jumlah persembahan yang diberikan oleh orang-orang yang hadir pada saat itu.

Beberapa penafsir dalam penjelasan lebih lanjut dari makalah ini menggambarkan bahwa pada saat pemberian persembahan selalu ada orang-orang yang bertugas untuk mencatat jumlah persembahan dan tujuan dari pemberian persembahan tersebut. Sebenarnya tradisi ini adalah tradisi kelanjutan dari tradisi persembahan kurban yang ada dalam kitab Imamat. Bedanya, pada masa itu, kurban diberikan dalam bentuk hewan kurban. Persembahan lainnya diberikan dalam bentuk perhiasan baik emas atau perak dengan syikal sebagai timbangan. Dan setiap pemberian kurban dilakukan berdasarkan ketentuan Hukum Taurat dengan memperhatikan seberapa besar kemampuan seseorang (Im. 1:1-17; 5:7,11; 12:8; $14: 21 ; 27: 8)$. Selain itu, setiap kurban diberikan berdasarkan tujuan masing-masing yang diatur sesuai dengan ketentuan Hukum Taurat tersebut (Im. 1:1-7:21).

\section{Ideologi dan Tradisi Yahudi yang Berakar Kuat pada Bait Allah}

Sampai pada tahun 70 S.M., sistem ideologi dan tradisi bangsa Yahudi masih berpusat pada Allah, Bait Suci dan Torah. ${ }^{24}$ Sistem ini merupakan sistem yang awalnya diterapkan oleh Ezra dan merupakan penggambaran dari sistem Nomokrasi yang ada di Israel. Salah satu peraturan yang paling ditekankan oleh sumber P dalam kitab Imamat adalah tentang masalah persembahan atau yang dalam Perjanjian Lama lebih dikenal dengan kurban. Kitab Imamat sendiri yang menjadi kunci dasar dari persembahan dan/atau kurban dalam masyarakat Israel ditulis oleh sumber P yang adalah kitab Kekudusan dengan memperhatikan milieu sumber tersebut.

Berdasarkan peraturan-peraturan yang tertera dalam kitab hukum Kekudusan tersebut, penulis melihat bahwa kuatnya tradisi yang dipegang oleh umat Israel dan ancaman tentang sanksi agama menjadi alasan mengapa perempuan janda dan miskin yang digambarkan dalam teks ini keukeuh untuk tetap memberikan persembahan walaupun dia hampir sama sekali tidak memiliki uang.

3. Jumlah Persembahan sebagai Pengungkap Identitas dan/atau Status Seseorang dalam Masyarakat

Ada pembagian kelas yang jelas dalam masyarakat Yahudi pada masa itu mulai dari golongan tertinggi sampai ke golongan terendah dalam masyarakat Yahudi. Orang-orang Saduki misalnya, adalah kaum Imamat yang merupakan kelompok orang yang kaya raya. Meski tidak semuanya menjadi imam, mereka tetap adalah

\footnotetext{
${ }^{23}$ Edwards, The Gospel, 380.

24 Seth Schwartz, Imperialism and Jewish Society 200 B.C.E To 640 C.E (Princeton: Princeton University Press, 2001), 62-67.
} 
orang-orang kaya dan menjadi golongan tuan tanah dalam masyarakat Yahudi. Dari sini juga para Imam besar umumnya berasal. Kaum Sanhendrin umumnya adalah orang-orang yang berpengaruh besar dalam urusan agama maupun politik, sehingga dapat diperkirakan bahwa mereka juga adalah golongan para bangsawan. Para Ahli Taurat merupakan golongan baru dalam masyarakat Yahudi yang juga merupakan golongan kelas atas. Sedangkan kaum Farisi adalah kaum ekslusif dalam keagamaan Yahudi yang diperkirakan juga merupakan orang-orang dari kelas atas dalam agama Yahudi. Di bawah mereka ada para Yahudi Perantauan, golongan Qumran atau Essenes, para Zelot dan orang-orang Samaria. ${ }^{25}$ Pembedaan ini sudah diketahui secara umum dalam masyarakat Yahudi dan menjaadi sangat kentara dalam Bait Suci terutama dalam ruangan persembahan. Edward menjelaskan bahwa di Bait Suci Yerusalem memang ada banyak orang yang datang untuk memberikan persembahan. Selain untuk beribadah, salah satu fungsi dari Bait Suci adalah untuk tempat penyimpanan dan/atau administrasi sebagian besar kekayaan mereka.

Biasanya saat seseorang memberikan persembahan, orang itu akan memberitahukan kepada para imam tujuan dari persembahan dan besaran jumlah yang diberikan. Ada yang membayar untuk kepentingan pajak, pengelolaan Bait Allah, persembahan umum, penghidupan kaum Lewi, persepuluhan dan pembayaranpembayaran lain yang dikelola oleh para pengurus Bait Allah. Pada masa kekaisaran Romawi dan kepemimpinan Herodes, Bait Allah dijadikan pusat administrasi. Karena itu, bisa dibayangkan ada begitu banyak orang kaya yang dengan suara nyaring menyebutkan jumlah persembahan atau uang mereka dan tujuan pemberian persembahan tersebut. Semakin banyak jumlah yang diberikan maka akan semakin banyak orang yang akan memperhatikan dan kagum akan orang tersebut. ${ }^{26}$ Pemberian persembahan dalam hal ini menjadi ajang untuk menunjukkan eksistensi pribadi baik itu status sosial dalam masyarakat, posisi dan kesuksesan rohani seseorang.

4. Polemik yang Muncul sebagai Akibat dari Pemberian Persembahan

Penulis melihat ada beberapa polemik yang muncul dan berakar dari ruang persembahan ini, antara lain:

a. Korupsi yang terjadi di Bait Allah

Sampai pada masa itu, kaum Lewi bertanggung jawab sebagai pengawas sekaligus pengurus dan/atau pengelola Bait Allah. Berdasarkan peraturan yang tertera dalam Torah, para Lewi hidup dari hasil persembahan umat. Tradisi ini membuat semua orang baik kaya ataupun miskin tetap memberikan persembahan untuk penghidupan para Lewi ini. Ada satu kotak persembahan yang memang diperuntukkan bagi para Lewi di antara tiga belas kotak persembahan yang ada. Sementara pada masa itu merupakan masa di mana perekonomian negara dalam keadaan terpuruk akibat penjajahan Romawi masa itu. Sementara banyak rakyat hidup miskin, para Lewi mampu menghasilkan kekayaan yang luar biasa dalam bentuk iuran, pajak, dan berbagai bentuk donasi (2 Raj. 14:4).

Orang-orang datang untuk memberikan persembahan kepada Allah di Bait Allah. Tradisi ini berlaku bagi setiap orang Yahudi, sehingga tidak hanya orang kaya, orang miskin pun datang untuk memberikan persembahan, iuran, pajak, dll. Peraturan awal pada masa Mozaic adalah bahwa orang Lewi hidup dari Bait Allah dan rakyat bertugas untuk memberikan persembahan sekaligus mengurus kehidupan para Lewi

\footnotetext{
${ }^{25}$ Wismoady Wahono, Di Sini Kutemukan (Jakarta: BPK Gunung Mulia, 2011), 325-39.

${ }^{26}$ Francis Foulkes, How The Good News Began (Nigeria: African Christian Press, 1986), 195.
} 
ini. Masalahnya adalah karena perubahan zaman, efek dari penjajahan Persia ke Yunani, pajak yang tinggi, membuat meskipun tradisi ini terus berlanjut, tindakan ini justru hanya memperkaya para rohaniawan yang ada di Bait Allah. Para rohaniawan ini, baik Sanhedrin, Saduki, Ahli Taurat, dll., menjadi masyarakat golongan kelas satu dalam susunan masyarakat Yahudi pada masa itu, mereka dihormati karena status sekaligus kekayaan mereka yang sebenarnya salah satunya bersumber dari orangorang miskin. ${ }^{27}$ Dengan demikian, Bait Suci menjadi tempat di mana terjadi "perampokan" bagi orang-orang miskin. ${ }^{28} \mathrm{Hal}$ ini juga dipengaruhi oleh adanya penggunaan uang yang mulai berkembang pesat pada abad ke- 4 sampai ke- 3 s.M., termasuk di Yerusalem, maka persembahan yang diberikan ke Bait Allah umumnya tidak lagi hanya dalam bentuk hewan untuk kurban baik itu kurban bakaran, sembelihan, penghapus dosa, dll. Kebanyakan kurban persembahan diberikan dalam bentuk uang ataupun emas.

Bait Allah sebenarnya merupakan tempat terpenting bagi masyarakat Yahudi karena tempat ini merupakan perwujudan keinginan dan hasrat peribadahan mereka. ${ }^{29}$ Di dalam Bait Allah ini ada Imam Besar yang menjadi symbol dan wakil semua orang Yahudi untuk berjumpa dengan Allah di Ruang Maha Kudus. Karena itu, ia dan seluruh keluarganya harus hidup tanpa cela. Di antara semua orang Yahudi, Imam Besar memiliki kedudukan tertinggi hampir di atas semua manusia. Karena itu, di setiap kemunculannya, ia selalu diiringi oleh para pengiring yang juga merupakan orang-orang yang dihormati. Ia tidak hanya memiliki pengaruh keagamaan namun juga pengaruh politik bahkan jika ia sudah turun dari jabatannya ini. Hanya saja, pada masa Herodes dan kekaisaran Romawi, ketentuan ini berubah. Mereka memperlakukan jabatan ini sesuka mereka. Mereka mengangkat dan memberhentikan Imam Besar demi kepentingan politik. Karena itu, di antara para imam sering juga terjadi perebutan kekuasaan dan disertai iri hati satu sama lain. Kebanyakan Imam Besar yang terpilih berasal dari keluarga kaya dan juga ingin mempunyai pengaruh politik. Sehingga agar dapat mempunyai kedudukan ini, tidak sungkan mereka bertindak kasar satu sama lain. ${ }^{30}$ Selain untuk tempat persembahan, pembayaran pajak, penghidupan Lewi, rumah persembahan juga memiliki kegunaan lain. Orang-orang pada masa itu percaya bahwa Bait Allah adalah tempat yang aman untuk tempat penyimpanan. ${ }^{31}$

\section{b. Perlakuan yang tidak adil terhadap Kaum Miskin}

Karena kebiasaan orang memberitahukan jumlah persembahan dan tujuan dari persembahan itu, para pengawas persembahan pun akan melakukan hal yang sama dengan orang-orang pada umumnya yaitu memperhatikan pemberian yang besar dari orang-orang kaya tersebut. ${ }^{32}$ Masalah baru muncul karena pemberian dari orang-orang kaya ini akan mengerdilkan pemberian dari orang-orang yang menengah ke bawah apalagi dari orang-orang miskin. ${ }^{33}$ Yesus sendiri mengabaikan orang-orang kaya yang memberikan persembahan namun kemudian bersuara nyaring seperti canang atau terompet yang bergemerincing (Mat. 6:2). ${ }^{34}$ Dengan

\footnotetext{
${ }^{27}$ David E. Garland, The NIV Application Commentary: Mark (USA: Zondervan, 1996), 482.

${ }^{28}$ Garland, Mark, 483.

${ }^{29}$ Wahono, Di Sini Kutemukan, 322.

${ }^{30}$ Wahono, Di Sini Kutemukan, 323.

${ }^{31}$ James R. Edwards, The Gospel According to Mark (Grand Rapids: William B. Eerdmans, 2002) ,380.

${ }^{32}$ Garland, Mark, 481.

${ }^{33}$ Garland, Mark, 481.

${ }^{34}$ Garland, Mark, 481.
} 
demikian, akan muncul dua pembagian kelas yang nyata dari peristiwa pemberian persembahan ini. Para Lewi akan segera memandang dan tertarik kepada orangorang yang memberi persembahan dalam jumlah besar dan terjadi pembedaan perlakuan terhadap kedua belah pihak. ${ }^{35}$

Umumnya, persembahan yang diberikan dalam bentuk emas dan perak dan mata uang yang dari kekaisaran Roma pada masa itu. Orang-orang yang memberi persembahan dalam jumlah besar menjadi orang-orang dari kelas yang kaya dan sebaliknya mereka yang miskin karena sedikitnya jumlah pemberian yang diberikan kepada Bait Allah. Berdasarkan jumlah persembahan yang diberikan akan terungkap status sosial orang tersebut yang berefek pada cara memperlakukan orang tersebut dalam Bait Allah dan masyarakat.

Pemberian dua koin yang diberikan oleh janda miskin tersebut adalah persembahan yang terdiri dari dua lepta. Lepta merupakan ukuran uang yang paling kecil dalam masyarakat Romawi Yunani. Lepta ini baru memiliki arti sebagai uang jika berjumlah dua lepta atau dua koin. ${ }^{36}$ Dengan demikian, persembahan janda miskin ini merupakan ukuran terkecil dalam mata uang Yunani masa itu. Pemberian ini tentu tidak menarik perhatian para imam besar. ${ }^{37}$ Karena itu, penghormatan terhadap perempuan ini berbeda dengan yang diterima oleh orang-orang kaya. Dari sini, pengalaman ketidakadilan dalam Bait Allah tergambarkan.

\section{Implikasi Etis Narasi Persembahan Janda Miskin dalam Penegakkan Keadilan}

Dari hasil telaah terhadap persoalan sosial yang tergambar melalui narasi janda miskin dalam Markus 12:41-44 tersebut, penulis melihat beberapa hal penting berikut antara lain:

\section{Perubahan Paradigma Persembahan}

Tradisi pemberian persembahan ini terus diteruskan oleh para rasul sampai dengan gereja-gereja di masa kini. Downs secara khusus dalam bukunya The Offering of the Gentiles membahas tentang jemaat non Yahudi yang dididik oleh Paulus untuk melibatkan diri dalam memberikan persembahan untuk mendukung kegiatan misi rasul Paulus dan untuk membantu orang-orang miskin. ${ }^{38}$ Buku ini menginterpretasikan beberapa pengertian dari pengumpulan persembahan itu sendiri yaitu sebagai suatu peristiwa eskatologis, kewajiban setiap orang percaya, sebuah persembahan yang bersifat ekumenis dan satu kegiatan yang bertujuan untuk memberi bantuan materi. ${ }^{39}$ Namun demikian, ada perubahan hakikat persembahan dalam PL dan PB dan masa kini. PL mengenal persembahan dalam bentuk upacaraupacara kurban, persepuluhan, persembahan buah sulung, dll. PL juga secara khusus membuat peraturan tentang cara memberikan persembahan, jumlah dan/atau bentuk persembahan, alasan memberikan persembahan, dan waktu memberikan persembahan. Jika terjadi kesalahan dalam pemberian persembahan, individu yang diwajibkan memberikan persembahan tersebut dapat dikenai sanksi (Im. 27:31).40 Dalam gereja Abad pertama, persembahan dipahami sebagai perjamuan. Andar

\footnotetext{
${ }^{35}$ G.A. Chadwick, The Gospel According to St. Mark (London: Hodeber n' Stroughton), 344.

${ }^{36}$ Alvah Horey, ed.al., American Commentary on the New Testament (Philadelphia: American Baptist Publication Society, 1881), 178.

${ }^{37}$ Charles R. Erdman, The Gospel of Mark (Philadephia: The Westminster Press, 1921), 171.

${ }^{38}$ David J. Downs, The Offering of the Gentiles: Paul's Collection for Jerusalem in Its Chronological, Cultural and Cultic Contexts (Grand Rapids: William B. Eerdmans Publishing Company, 2008).

${ }^{39}$ Downs, The Offering of the Gentiles, 3-29.

${ }^{40}$ Andar Ismail, Selamat Berbakti (Jakarta: BPK Gunung Mulia, 2008), 117.
} 
Ismail menyatakan bahwa hal ini dilakukan karena pada masa itu belum ada pemisahan pengertian antara perjamuan kasih (agape) dan Perjamuan Kudus (ekaristi). Jemaat membawa baik bahan-bahan makanan, makanan ataupun minuman untuk dapat saling berbagi dengan orang lain terutama orang miskin. Pada masa gereja mula-mula tidak ada lagi ketentuan tentang jumlah, bentuk, atau waktu dalam memberikan persembahan. Besaran dan bentuk persembahan diberikan secara sukarela (2 Kor. 9:6-7). Dengan demikian, persembahan dalam PL umumnya lebih bersifat spiritual sementara persembahan dalam PB lebih bersifat diakonal. ${ }^{41}$

Ada perubahan dalam persembahan disebabkan perkembangan yang terjadi pada orang-orang percaya. Pelayanan Rasul Paulus yang menjangkau orang-orang di luar Yahudi menyebabkan tradisi persembahan dalam budaya Yahudi mulai mendapatkan makna yang baru. Orang percaya setelah masa Rasul Paulus tidak lagi berpusat kepada Bait Allah, para imam, orang Lewi, ahli Taurat, dll. Sejak kematian dan kebangkitan Yesus, segala pujian dan penyembahan langsung diarahkan kepada Allah. Hal ini juga secara praktis mengubah sistem persembahan dalam jemaat. Tidak ada patokan khusus seperti dalam kitab Keluaran, Imamat ataupun Ulangan. Prinsip pemberian persembahan adalah sukarela. Jemaat juga tidak perlu menyebutkan besaran persembahan mereka. Di lain pihak, tujuan persembahan bagi jemaat mulamula yang adalah pelayanan bagi kaum miskin dan dukungan pelayanan misi membuat keharmonisan hubungan antara kedua status ekonomi sosial ini dan jurang pemisah antara orang-orang yang kaya dan miskin menjadi kabur.

\section{Gereja dan Kemiskinan di Masa Kini}

Untuk sampai kepada peran gereja terhadap kaum miskin, Gutierrez terlebih dahulu memberikan gambaran terhadap jati diri gereja itu sesungguhnya. Menurut Gutierrez, gereja setidaknya memiliki tiga jati diri antara lain: Pertama, persekutuan orang-orang yang percaya kepada Kristus atau pengikut Kristus (Yoh. 1:43). Mengikut Yesus dilakukan secara sadar, bebas dengan arah atau tujuan tertentu. Mengikut Yesus tidak bersifat individual melainkan menjadi sebuah perjalanan kolektif yang bergerak dari pertemuan dengan Allah kepada pertemuan dengan komunitas termasuk kepada orang-orang yang lemah dan papah. ${ }^{42}$ Kedua, sakramen sejarah. Menurut Gutierrez, menyebut gereja sebagai sakramen sama artinya dengan menyebutkan rencana penyelamatan Allah yang terpenuhi dalam sejarah melalui Yesus Kristus. Gereja dalam hal ini harus mewartakan diri pada dunia sekaligus bersedia membiarkan diri untuk dievangelisasi oleh dunia sehingga terjadi dialektis antara gereja dan dunia. Selain itu, gereja juga perlu mengambil peran dalam pembebasan, melepaskan diri dari tatanan sosial yang tidak adil, dan menunjukkan solidaritas terhadap ketimpangan sosial yang terjadi terutama pada upaya pembebasan kaum miskin. Gereja harus menunjukkan kehadiran Kerajaan Allah kepada dunia berupa perdamaian, keadilan, kehidupan dan kasih. ${ }^{43}$ Ketiga, gereja sebagai komunitas ekaristi. Menurut Gutierrez, tugas ekaristi gereja adalah merayakan dengan penuh kegembiraan anugerah karya keselamatan Allah melalui Kristus bagi dunia. Dalam ekaristi terungkap komunitas persaudaraan yang ditebus

${ }^{41}$ Kecuali adanya persembahan untuk orang-orang miskin setiap tahun ketiga dalam PL, lihat Ismail, Selamat, 118.

${ }^{42}$ Chen, Teologi, 114-16.

${ }^{43}$ Chen, Teologi, 116-18. 
oleh Yesus Kristus. Komunitas ini melaksanakan perutusan bagi kaum miskin dan hina. ${ }^{4}$

Berdasarkan pengertian tersebut di atas, Gutierrez melihat bahwa gereja diutus untuk menyatakan pembebasan bagi semua orang dengan pilihan mendahulukan kaum miskin. Dalam pertemuan para uskup di Medellin tahun 1968 terdapat kata kunci bagi perutusan gereja dewasa ini yaitu "Pilihan mendahulukan kaum miskin" yang diartikan oleh Gutierrez sebagai kehendak bebas seseorang dalam menentukan prioritas dan dalam hal ini, orang-orang yang miskin secara material menjadi prioritas utama untuk didahulukan. Tema ini tidak mengandung arti bahwa orangorang kaya tidak dipedulikan, tetapi suatu undangan untuk terlibat dalam membangun masyarakat yang adil dan bersaudara. ${ }^{45}$

Situasi sosial dalam gereja-gereja masa kini sudah jauh berbeda dengan pergumulan yang dialami oleh orang-orang pada zaman Yesus melayani. Gereja masa kini sudah mulai memperhatikan dan/atau menunjukkan solidaritas terhadap orangorang yang kurang mampu. Di gereja sendiri ada berbagai jenis persembahan yang diberlakukan di gereja sampai saat ini. Secara umum, persembahan-persembahan yang wajib dikumpulkan dalam gereja adalah persembahan mingguan, ucapan syukur, diakonia dan perpuluhan. Selain itu, setiap anggota gereja juga dikenai tanggungjawab kepada gereja berupa iuran wajib baik itu iuran keanggotaan dan dana kematian. Namun untuk beberapa gereja aliran Evangelikal, ada lagi persembahan khusus seperti persembahan misi. Dalam beberapa kegiatan tertentu, jemaat juga diminta terlibat dalam pemberian "janji iman" entah itu untuk pembangunan gedung, acara-acara besar, dll. Untuk acara-acara besar, biasanya panitia yang ditentukan akan membuat proposal yang diberikan kepada jemaatjemaat yang mampu secara ekonomi untuk dapat mensponsori acara yang dilakukan di gereja tersebut. Sementara bagi yang kurang mampu, pemungutan biaya ini dilakukan secara sukarela.

Memang ada terdapat beberapa prapaham yang mempertanyakan pemilihan para penatua atau majelis yang umumnya merupakan orang-orang dari kelompok jemaat dengan status ekonomi menengah ke atas. Namun demikian, pada masa kini, dari dalam jemaat sendiri tidak banyak yang mempermasalahkan lagi hal ini. Setiap jemaat "yang terpanggil, mau dan mampu" mulai mengambil bagian dalam pelayanan secara sukarela untuk melayani dalam berbagai bidang pelayanan mulai dari pelayanan Anak, Remaja, Pemuda, Persekutuan kaum perempuan, persekutuan kaum bapak, diakonia, misi, dll. Ada banyak lini pelayanan dalam gereja yang bisa diisi sesuai dengan potensi masing-masing sehingga persoalan tentang siapa yang dipilih menjadi majelis dalam gereja sudah tidak mengembang lagi.

Selain itu, khusus untuk kaum miskin, setiap gereja sudah memiliki komisi diakonia sendiri yang dipilih untuk memberi perhatian kepada orang-orang miskin dalam jemaat dan membuat program-program khusus untuk acara-acara sosial di luar jemaat atau gereja. Banyak ahli manajemen gereja mulai menaruh perhatian besar pada pelayanan diakonia dalam jemaat. Banyak dari anggota jemaat yang sudah mengambil bagian yang sama dalam pelayanan diakonia bagi orang-orang yang kurang mampu baik dari dalam maupun di luar jemaat. Untuk itu, keuangan yang ada dalam gereja juga dikelola oleh orang-orang terpilih dan dapat dipercaya, sehingga korupsi dan kepentingan politis yang mungkin akan menindas kehidupan

\footnotetext{
${ }^{44}$ Chen, Teologi, 118-20.

${ }^{45}$ Chen, Teologi, 121.
} 
kaum miskin seperti yang ada pada masa pascapembuangan di bawah jajahan Yunani sampai kepada masa jajahan Romawi sudah tidak terlalu menonjol lagi.

Sampai saat ini, jarang ada catatan khusus di mana ada penelantaran terhadap kaum miskin di dalam gereja. Anggota gereja secara kompak menaruh perhatian besar terhadap kemiskinan. Kebanyakan konflik terjadi karena perbedaan pendapat, perbedaan pemahaman teologi, gap yang timbul karena pengelompokanpengelompokan dalam jemaat, pengangkatan dan pemberhentian Majelis, dll. Namun masalah-masalah ini tidak disebabkan karena adanya perbedaan perlakuan, diskriminasi, pengucilan terhadap kaum miskin.

\section{Solidaritas terhadap Kaum Miskin}

Meski demikian, tidak berarti bahwa tidak ada cacat dalam gereja dalam penanganan kaum miskin terutama di luar lingkungan gereja. Untuk itu, perlu satu gerakan solidaritas bagi kaum miskin yang dimulai dari dalam diri sendiri, jemaat, gereja, masyarakat dan negara. Sampai saat ini, jumlah kemiskinan di seluruh dunia belum berkurang. Di Indonesia, angka kemiskinan ditahun 2017 mulai mengalami pengurangan dari Maret 2017 dengan angka 10,64\% menjadi 10,12\% pada September 2017.46 Terjadi pengurangan jumlah kemiskinan di Negara Indonesia disebabkan oleh upah buruh yang meningkat dan nilai beberapa komoditi yang berkurang. Meskipun beberapa komoditi lain menunjukkan kenaikan namun jumlahnya tidak terlalu banyak. Hanya saja, penggajian buruh yang ditetapkan oleh pemerintah perhari acapkali tidak sesuai dengan realisasi di lapangan sehingga upaya untuk mengentaskan kemiskinan itu sendiri menghadapi kendala.

Laporan ini menunjukkan bahwa negara dalam hal ini pemerintah telah bekerja keras untuk mengurangi angka kemiskinan struktural di Indonesia. Namun pemerintah juga perlu bekerjasama dan bersikap tegas terhadap dan dengan para pemilik badan usaha agar upah buruh yang telah ditetapkan oleh pemerintah dapat direalisasikan oleh pemilik badan usaha tersebut. Gereja baik secara pribadi maupun bekerjasama dengan pemerintah dapat memberi sumbangsih dalam mengurangi ketidakadilan yang terjadi dalam masyarakat. Seperti kritik terhadap para pemilik badan usaha yang kemungkin juga menjadi salah satu anggota dalam gereja agar bersikap adil dan membayar upah buruh sesuai dengan ketentuan pemerintah.

Kemiskinan jenis lain adalah kemiskinan individual. Untuk kasus ini, pendidikan dalam bidang kognitif, terutama karakter dan/atau moral dan spiritual diperlukan agar pribadi-pribadi yang terbiasa dengan hidup miskin ini mau keluar dari kemiskinan dirinya tersebut. Gereja dalam hal ini bisa mengambil tanggung jawab untuk memperhatikan orang-orang dengan kasus seperti ini, memberi konseling, nasihat, anjuran, agar mereka dapat bangkit melawan kemalasan atau sifat enggan untuk bekerja.

\section{Kesimpulan}

Sampai saat ini, gereja dan pemerintah serta organisasi-organisasi sosial lain telah melakukan banyak usaha untuk menangani kasus kemiskinan dan mendatangkan harapan untuk kehidupan yang lebih baik di masa depan bagi setiap orang. Wajah kemiskinan yang ada di sekitar penulis saat ini sudah tidak seseram atau menakutkan seperti yang terjadi beberapa abad yang lalu di negera-negara

\footnotetext{
46 Profil Kemiskinan di Indonesia September 2017 No. 05/01/Th. XXI, 2 Januari 2018 lihat dalam https://www.bps.go.id/pressrelease/2018/01/02/1413/persentase-penduduk-miskin-september-2017mencapai-10-12-persen.html. Tabel 6, hlm. 7.
} 
seperti Amerika Latin, India atau negara-negara lain. Faktor alam Indonesia juga menjadi pendukung kesejahteraan dalam masyarakat Indonesia, sehingga walaupun ada masyarakat yang hidup miskin atau tidak mampu memenuhi kuota pengeluaran perkapita, orang-orang tersebut masih dapat hidup nyaman di tanah Indonesia. Ada perubahan besar dalam dunia pada beberapa dekade terakhir di seluruh dunia sebagai efek dari arus media sosial. Banyak usaha dapat dilakukan untuk mengurangi angka kemiskinan atau juga menolong orang-orang miskin melalui media sosial meski tidak tertutup kemungkinan ada juga yang mengambil keuntungan dari pemberitaan tentang kemiskinan ini. Namun demikian, bisa saja kemiskinan yang nyata-nyata seperti gambaran yang ada di dalam tulisan Markus, Hinrich, Rauschenbusch, Gutierrez dan beberapa penulis lain masih ada sampai saat ini. Hanya penulis belum pernah menjumpainya secara langsung terutama di tempattempat di Indonesia.

Ada pembedaan perlakukan antara orang kaya dan miskin sampai saat ini di berbagai tempat. Ada kemudahan fasilitas yang diberikan bagi orang-orang kaya yang mampu membayar fasilitas tersebut dengan harga yang pantas. Penulis menilai hal ini sebagai kewajaran dan bukan merupakan masalah sosial. Pemerintah Indonesia sendiri pada masa kini telah melakukan upaya agar kesejahteraan bisa dirasakan oleh semua masyarakat. Pemerintah juga menjamin fasilitas kesehatan dan pendidikan bagi masyarakat Indonesia secara menyeluruh, adil dan merata. Bagi masyarakat yang "benar-benar miskin" diberikan subsidi silang untuk fasilitas kesehatan yaitu BPJS JKN tanpa perlu membayar asuransi bulanan. Ada sekolah gratis dari SD sampai SMP untuk anak-anak yang bersekolah di sekolah negeri. Hanya perlu kerjasama yang baik antara pribadi-pribadi dan dinas terkait untuk pengurusan administrasi. Dari berbagai strategi yang dilakukan oleh pemerinta, secara struktural, gambaran kemiskinan mulai memudar.

Pada akhirnya, penulis melihat bahwa mungkin perlu ada perjumpaan terlebih dahulu dengan mereka agar melalui perjumpaan dengan orang-orang miskin, baik penulis dan kita juga dapat memperoleh pemahaman yang lebih tentang hati Allah, tidak hanya bagi kita sendiri, bagi orang-orang miskin dan lemah, namun juga bagi setiap orang diseluruh dunia. Namun karena orang-orang miskin merupakan orangorang yang paling rentan untuk mendapat perlakukan tidak adil, maka perlu suatu formulasi solidaritas terhadap kaum miskin demi mewujudkan Kerajaan Allah di dunia.

\section{Referensi}

Barclay, William. Pemahaman Alkitab Setiap Hari: Injil Markus. Jakarta: BPK Gunung Mulia, 2003.

Chadwick, G.A. The Gospel According to St. Mark. London: Hodeber n' Stroughton.

Chen, Marthin Teologi Gustavo Gutierrez: Refleksi dari Praksis Kaum Miskin. Yogyakarta: Kanisius, 2002.।

Delorme, J. Injil Markus. Yogyakarta: Kanisius, 1978.

Downs, David J. The Offering of the Gentiles: Paul's Collection for Jerusalem in Its Chronological, Cultural and Cultic Contexts. Grand Rapids: William B. Eerdmans Publishing Company, 2008.

Edwards, James R. The Gospel According to Mark. Grand Rapids: William B. Eerdmans, 2002.

Erdman, Charles R. The Gospel of Mark. Philadephia: The Westminster Press, 1921. Francis Foulkes, How The Good News Began. Nigeria: African Christian Press, 1986. 
Garland, David E. The NIV Application Commentary: Mark. USA: Zondervan, 1996.

Gutierez, Gustavo. A Theology of Liberation: History, Politics, and Salvation. New York: Orbis Book, 1983.

Horey, Alvah ed.al., American Commentary on the New Testament. Philadelphia: American Baptist Publication Society, 1881.

Ismail, Andar. Selamat Berbakti. Jakarta: BPK Gunung Mulia, 2008.

Schwartz, Seth. Imperialism and Jewish Society 200 B.C.E To 640 C.E. Princeton: Princeton University Press, 2001.

Wahono, Wismoady. Di Sini Kutemukan. Jakarta: BPK Gunung Mulia, 2011.

\section{WWW}

https://www.kbbi.web.id/miskin diunduh 11 Mei 2018.

https://www.merriam-webster.com/dictionary/poor diunduh 11 Mei 2018.

https://en.oxforddictionaries.com/definition/poor diunduh 11 Mei 2018.

https://dictionary.cambridge.org/dictionary/english/poor diunduh 11 Mei 2018.

Profil Kemiskinan di Indonesia September 2017 No. 05/01/Th. XXI, 2 Januari 2018 lihat

dalamhttps://www.bps.go.id/pressrelease/2018/01/02/1413/persentasependuduk-miskin-september-2017-mencapai-10-12-persen.html. 